\title{
Dampak Korupsi Terhadap Pertumbuhan Ekonomi: Studi Kasus 4 Negara di ASEAN
}

\section{(Impact Corruption on Economic Growth: A Case Study of 4 Countries in ASEAN)}

\author{
Akhmad Faisal Lutfi ${ }^{*}$, Zainuri, Herman Cahyo Diartho \\ Jurusan Ilmu Ekonomi dan Studi Pembangunan, Fakultas Ekonomi dan Bisnis, Universitas Jember (UNEJ) \\ Jln. Kalimantan 37, Jember 68121 \\ E-mail: faisalutfi@gmail.com
}

\begin{abstract}
Abstrak
Dewasa ini fenomena pengaruh korupsi terhadap pertumbuhan ekonomi telah menjadi isu perdebatan yang cukup panas, baik secara teoritis maupun empiris. Penelitian ini menggunakan analisis data panel dengan pendekatan Random Effect Model guna mengetahui apakah korupsi mempunyai dampak negatif terhadap pertumbuhan ekonomi di 4 negara ASEAN selama periode 2004-2015. Hasil analisis menunjukkan bahwa variabel korupsi mempunyai pengaruh negatif terhadap pertumbuhan ekonomi meski tidak signifikan, sementara variabel lain yang mempunyai pengaruh positif signifikan terhadap pertumbuhan ekonomi adalah investasi publik. Hasil penelitian ini mengkonfirmasi bahwa dampak negatif dari korupsi tidak secara langsung mempengaruhi pertumbuhan ekonomi melainkan lebih mengarah pada inefisiensi proses produksi dan misalokasi sumber daya.
\end{abstract}

Kata Kunci: korupsi, pertumbuhan ekonomi, ASEAN, data panel, Random Effect Model.

\begin{abstract}
Today the phenomenon of the influence of corruption to economic growth has been a fairly hot issue of debate, both theoretically and empirically. The research uses a data panel analysis with a Random Effect Model approach to determine if corruption has a negative impact on economic growth in 4 ASEAN countries over the period of 2004-2015. Analysis results show that variable corruption has a negative influence on economic growth despite being insignificant, while other variables that have a significant positive influence on economic growth are public investments. The results of this study confirm that the negative effects of corruption do not directly affect economic growth but rather lead to the inefficiencies of production processes and the misallocation of resources.
\end{abstract}

Keywords: corruption, economic growth, ASEAN, panel data, Random Effect Model.

\section{Pendahuluan}

Dampak korupsi pada aspek ekonomi menjadi suatu permasalahan yang dapat menghambat pembangunan ekonomi disetiap negara, baik pada negara sedang berkembang maupun negara maju. Banyak negara yang mulai serius mempertimbangkan bahaya korupsi terhadap perekonomian dengan cara membentuk lembaga atau departemen yang mampu mencegah dan mengendalikan korupsi tersebut. Demikian pula dengan organisasi internasional yang juga turut mendirikan badan anti korupsi yang ditujukan untuk meningkatkan kesadaran akan dampak buruk dari korupsi terhadap pertumbuhan ekonomi (Huang, 2015). Hal tersebut tidak terlepas dari meningkatnya studi empiris yang menunjukkan bahwa korupsi memiliki konsekuensi yang dapat mengurangi tingkat investasi, menurunkan produktivitas belanja publik, mendistorsi alokasi sumber daya dan pada akhirnya berimbas pada terhambatnya pertumbuhan ekonomi (Dreher \& Herzfeld, 2011; Mauro, 1995; Rose-Ackerman, 1996). Bahkan, International Monetary Fund (2016) memperkirakan lebih dari US\$ 1,5 - 2 triliun atau sekitar 2\% dari total Gross Domestic Product (GDP) dunia hilang setiap tahunnya dikarenakan korupsi dan penyuapan.

Para ekonom, sejarawan dan ahli politik telah terlibat dalam perdebatan yang panjang tentang apakah korupsi dapat membahayakan bagi pertumbuhan ekonomi suatu negara.
Ada argumentasi menarik yang menyatakan bahwa korupsi dapat memberikan beberapa manfaat yang positif. Hal itu diungkapkan oleh Leff (1964); Leys (1965); Lui, (1985) yang menyatakan bahwa korupsi dapat berfungsi sebagai pembayaran insentif untuk menghapus peraturan pemerintah yang tidak efisien, mempercepat birokrasi serta mendapatkan kemudahan izin usaha yang lebih cepat dengan cara menyuap pejabat publik. Sejalan dengan itu, Huntington (1968) setuju dengan argumentasi bahwa korupsi memiliki pengaruh positif terhadap pertumbuhan ekonomi. Alasannya dikarenakan korupsi dapat meningkatkan efisiensi, terutama di sektor publik. Namun sebaliknya, Myrdal (1968) menyatakan bahwa korupsi dapat menyebabkan efisensi yang lebih rendah dan pada akhirnya memberikan hambatan bagi pembangunan suatu negara. Argumentasi tersebut didasarkan pada tindakan sengaja yang dilakukan oleh para pejabat publik dalam memberikan pelayanan yang lambat terhadap masyarakat guna memperoleh uang suap yang lebih banyak.

Banyak penelitian yang dilakukan untuk mengeksplorasi pengaruh korupsi terhadap pertumbuhan ekonomi karena keprihatinan atas dampak bahaya yang ditimbulkannya. Salah satu studi empiris lintas negara yang pertama kali dilakukan dalam menganalisis pengaruh korupsi terhadap pembangunan ekonomi adalah Mauro (1995) yang berfokus pada pertumbuhan GDP perkapita. Melalui metode estimasi dengan 68 negara sebagai sampel penelitian memperoleh

\footnotetext{
* Corresponding author
} 
hasil yang signifikan secara statistik yaitu negara-negara yang mempunyai tingkat korupsi tinggi berdampak pada nilai pertumbuhan PDB dan investasi yang lebih rendah. Berbagai penelitian yang serupa d'Agostino et al. (2016); Dridi (2013); Gyimah-Brempong (2002); Mauro (1995); Mo (2001); Poirson (1998); Shera et al. (2014); Tanzi (1998); Tsaturyan \& Bryson (2009) juga menemukan korupsi mempunyai dampak negatif yang signifikan terhadap pertumbuhan ekonomi di negara sampel penelitian.

Meski sebagian besar studi empiris setuju bahwa korupsi memiliki pengaruh negatif terhadap pertumbuhan ekonomi, beberapa studi empiris lainnya menunjukkan hal sebaliknya yang menyatakan bahwa dampak negatif korupsi terhadap pertumbuhan ekonomi tidak selalu terkonfirmasi bahkan cenderung berpengaruh positif. Penelitian Wedeman (1997) menemukan bahwa banyak negara menikmati pertumbuhan ekonomi yang pesat meskipun menghadapi tingkat korupsi yang tinggi. Penelitian yang dilakukan oleh Acemoglu \& Verdier (1998) menggunakan model teoritis menemukan bahwa adanya tingkat korupsi yang optimal ketika sebuah negara sedang mengejar maksimalisasi output nasional. Senada dengan penelitian yang dilakukan oleh Colombatto (2003) juga menunjukkan bahwa praktek korupsi di negaranegara berkembang atau negara totaliter justru membantu dalam mengurangi faktor-faktor tertentu yang meghambat pembangunan ekonomi. Bahkan penelitian Barreto (2001) menemukan korupsi berhubungan positif yang signifikan terhadap pertumbuhan PDB perkapita dengan menggunakan indikator korupsi yang sama dengan penelitian yang dilakukan Mauro (1995). Pernyataan tersebut dipertegas oleh penelitian Paksha Paul (2010) yang menemukan bahwa ada hubungan positif antara korupsi dan pertumbuhan ekonomi di Bangladesh.

Dalam 20 tahun terakhir, ASEAN telah membuat kemajuan yang signifikan dalam tingkat pendapatan perkapita. Namun di sisi lain, berdasar pada laporan hasil terbaru mengenai indeks korupsi dalam Corruption Perception Index (CPI) yang mencakup 177 negara mengungkapkan bahwa 7 dari 10 negara yang tergabung dalam anggota ASEAN berada pada skor dibawah angka 50 dimana CPI tersebut mempunyai skala penilaian antara 0 (sangat korup) - 100 (sangat bersih) (Transparency International, 2015). Hal ini jelas menimbulkan sebuah pertanyaan yakni apakah skor CPI yang rendah di negara-negara ASEAN khususnya pada 4 negara anggota (Indonesia, Malaysia, Thailand dan Vietnam) dapat mengancam pertumbuhan ekonomi atau justru tindakan korupsi dibutuhkan guna meningkatkan pertumbuhan ekonomi.

Gambar 1. CPI 4 negara ASEAN (Sumber: Transparency International)
Berdasar pada Gambar 1 menunjukkan bahwa CPI di 4 negara ASEAN sulit untuk mengalami peningkatan skor yang cukup besar, rata-rata peningkatannya hanya berkisar dalam beberapa poin saja. Misalnya saja Vietnam hanya mengalami peningkatan sebesar 2 angka pada tahun 2010 dan 2011 lalu kemudian stagnan sampai tahun 2015. Demikian pula dengan Thailand, Indonesia dan Malaysia yang angkanya tidak meningkat secara signifikan. Hal ini mengindikasikan bahwa lembaga-lembaga publik di negara-negara ASEAN masih kekurangan dalam hal transparansi dan akuntabilitas, minimnya penegakan undang-undang anti korupsi dan keterlibatan masyarakat sipil yang dibatasi. Hanya di Indonesia dan Thailand yang telah menerapkan kebebasan hukum dan informasi, sementara banyak otoritas atau lembaga anti korupsi di daerah yang belum menggunakan potensi kekuatan secara penuh dikarenakan kurangnya kemandirian operasional serta kapasitas sumber daya yang terbatas.

\section{Metode}

\section{Jenis dan Sumber Data}

Jenis data yang digunakan dalam penelitian ini adalah data sekunder dalam bentuk data panel yaitu gabungan data time series dan cross. Data yang digunakan dalam penelitian ini berasal dari laporan tahunan yang dikeluarkan oleh Transparency International, United Nation Educational, Scientific and Cultural Organization (UNESCO) dan data statistik yang dipublikasikan oleh World Bank.

\section{Populasi dan Sampel}

Rentang waktu yang digunakan dalam penelitian ini pada tahun 2004 sampai dengan 2015. Alasan dibalik penentuan rentang waktu tersebut dikarenakan untuk menghindari efek dari adanya krisis ekonomi dan moneter yang terjadi di kawasan ASEAN sebelum tahun penelitian. Sementara fokus objek penelitian ini adalah 4 negara di kawasan ASEAN yang terdiri atas Indonesia, Malaysia, Thailand, dan Vietnam.

\section{Model Penelitian}

Spesifikasi model penelitian ini mengadopsi model pertumbuhan ekonomi yang telah dipopulerkan oleh Barro (1991) dan Levine \& Renelt (1992). Kemudian model pertumbuhan ekonomi tersebut dimodifikasi dengan memasukkan korupsi sebagai variabel independen. Hal ini sesuai dengan literatur empiris tentang dampak korupsi terhadap pertumbuhan ekonomi yang dilakukan oleh d'Agostino et al. (2016) \& Gyimah-Brempong (2002). Berikut merupakan model ekonometrika dalam bentuk linier pada penelitian ini

$$
G D P=\alpha_{0}+\beta_{1} C O R+\beta_{2} P E D U+\beta_{3} P O P+\beta_{4} I N V+\beta_{5} O P E N+\varepsilon
$$

kemudian persamaan di atas ditransformasikan ke dalam sebuah model data panel menjadi:

$$
\begin{aligned}
& G D P_{i t}=\alpha_{0}+\beta_{1} C O R_{i t}+\beta_{2} P E D U_{i t}+\beta_{3} P O P_{i t}+\beta_{4} I N V_{i t}+\beta_{5} O P E N_{i t}+\varepsilon_{i t} \\
& \text { untuk } i=1,2, \ldots, N \text { dan } t=1,2, \ldots, T \\
& \text { dimana } \\
& \text { GDP : tingkat pertumbuhan GDP per kapita (\%) } \\
& C O R \quad: \text { korupsi (indeks) } \\
& P E D U \quad: \text { tingkat partisipasi pendidikan dasar }(\%) \\
& P O P \quad: \text { tingkat pertumbuhan penduduk (\%) }
\end{aligned}
$$




$$
\begin{array}{ll}
\multicolumn{1}{l}{\text { INV }} & \text { : investasi publik (\%) } \\
\multicolumn{1}{c}{\text { OPEN }} & \text { : keterbukaan perdagangan (\%) } \\
\alpha & : \text { konstanta (intercept) } \\
\beta_{1,2, \ldots, 5} & : \text { parameter (slope koefisien) dan } \\
\varepsilon & : \text { error } \\
N & \text { : banyaknya negara } \\
T & \text { : banyaknya waktu }
\end{array}
$$

\section{Metode Analisis Data}

Data panel merupakan data gabungan antara data cross section dan data time series. Data panel dapat diartikan sebagai data cross section yang dilakukan pengamatan berulang kali pada individu yang sama Murray (1946). Menurut Sunengsih et al. (2009), analisis regresi data panel adalah analisis regresi yang didasarkan pada data panel untuk mengamati hubungan antara satu variabel independen dengan satu atau lebih variabel dependen.

Dalam analisis model data panel dikenal tiga macam pendekatan estimasi yaitu Pooled Regression, Fixed Effect Model (FEM) dan Random Effect Model (REM). Pendekatan Pooled Regression yaitu mengestimasi model dengan menggunakan metode Ordinary Least Square sehingga dapat disebut pendekatan kuadrat terkecil. Pendekatan FEM yaitu memperhitungkan kemungkinan bahwa penelitian akan menghadapi masalah ommited variables dimana ommited variables mungkin membawa perubahan pada intercept time series atau cross section. Model ini menambahkan dummy variables untuk mengizinkan adanya perubahan intercept. Pendekatan REM yaitu memperbaiki efisiensi proses least squares dengan memperhitungkan error dari cross section dan time series.

Ada tiga pengujian yang digunakan dalam analisis metode data panel guna memilih model yang tepat yakni Uji Chow, Uji Hausman dan Uji Lagrange Multiplier. Uji Chow digunakan untuk memilih salah satu model pada regresi data panel, yaitu antara Pooled Regression dengan model efek acak (random effect model). Uji Hausman digunakan untuk memilih antara model efek acak (random effect model) dengan model efek tetap (fixed effect model). Uji Lagrange Multiplier digunakan untuk menguji adanya efek waktu, individu atau keduanya. Sementara itu, guna memeriksa persamaan regresi dalam data panel maka dibutuhkan Uji Simultan (Uji F) dan Uji Parsial (Uji $t$ ).

\section{Hasil dan Pembahasan}

\section{Hasil Analisis Statistik Deskriptif}

Pemaparan hasil analisis statistik deskriptif di 4 negara ASEAN menunjukkan bahwa secara keseluruhan variabel penelitian memiliki persebaran data yang sangat baik. Hal ini dapat dibuktikan melalui nilai standart deviasi yang memiliki angka lebih kecil dibandingkan dengan nilai rata-rata. Hasil lainnya menunjukkan adanya fluktuasi pada variabel penelitian dengan ditandai oleh angka nilai maksimum dan nilai minimum yang terpaut cukup jauh.

Tingkat pertumbuhan GDP per kapita di 4 negara ASEAN mengalami fluktuasi sangat besar dengan nilai minimum yang menunjukkan angka -4,16 dan nilai maksimum sebesar 7,51. Fluktuasi ini lebih banyak disebabkan oleh faktor eksternal yaitu dikarenakan adanya ketidakpastian kondisi perekonomian global akibat dari krisis subprime mortgage di
Amerika Serikat pada tahun 2008 sehingga memberikan dampak signifikan terhadap kondisi tingkat pertumbuhan GDP perkapita di 4 negara ASEAN pada tahun 2004 sampai dengan 2015 (Laporan Perekonomian Indonesia, 2015).

Peningkatan indeks persepsi korupsi yang dilihat pada variabel COR mengalami fluktuasi dalam rentang waktu 2004 sampai dengan 2015 meskipun angkanya tidak terlalu besar. Hal ini dapat dilihat dari nilai maksimum sebesar 52 dan nilai minimumnya menunjukkan angka 20. Dalam analisis statistik ini, faktor utama yang menyebabkan fluktuasi pada CPI di 4 negara ASEAN dikarenakan lemahnya penerapan demokrasi. Sebagai contoh bahwasannya Vietnam telah mengupayakan penegakan hukum dan penerapkan strategi anti korupsi yang komprehensif namun hal tersebut masih menimbulkan keraguan dalam pengaplikasiannya dikarenakan institusi demokrasi dan hak politik yang masih lemah (Transparency International, 2015).

\section{Pengujian Spesifikasi Model Regresi Data Panel}

\section{Uji Chow}

Tabel 1. Hasil Uji Chow

\begin{tabular}{cccc}
\hline Effects Test & Statistic & d.f. & Prob. \\
\hline Cross-section F & 1.001410 & $(3,39)$ & 0.4024 \\
$\begin{array}{c}\text { Cross-section Chi- } \\
\text { square }\end{array}$ & 3.562018 & 3 & 0.3128 \\
& & & \\
\end{tabular}

Sumber: Eviews, diolah

Berdasarkan hasil pengujian dengan Uji Chowpada Tabel 1 diperoleh nilai probabilitas Cross-Section F adalah $0.4024>$ $\alpha=0,05$ yang mengartikan bahwa menerima. Dengan diterimanya $H_{0}$ pada Uji Chow maka model regresi data panel yang tepat digunakan adalah Pooled Regression.

\section{Uji Hausman}

Tabel 2. Hasil Uji Hausman

\begin{tabular}{cccc}
\hline Test Summary & $\begin{array}{c}\text { Chi-Sq. } \\
\text { Statistic }\end{array}$ & $\begin{array}{c}\text { Chi-Sq. } \\
\text { d.f. }\end{array}$ & Prob. \\
\hline Period random & 3.615269 & 5 & 0.6060 \\
\hline
\end{tabular}

Sumber: Eviews, diolah

Berdasarkan hasil pengujian dengan Uji Hausman pada Tabel 2 diperoleh nilai probabilitas Chi-square adalah $0.6060>\alpha=$ 0,05 yang mengartikan bahwa menerima $H_{0}$. Dengan diterimanya $H_{0}$ pada Uji Hausman maka model regresi data panel yang tepat digunakan adalah Random Effect Model.

\section{Uji Lagrange Multiplier}

Tabel 3. Hasil Uji Lagrange Multiplier

\begin{tabular}{cccc}
\hline $\begin{array}{c}\text { Null (no rand. } \\
\text { effect) } \\
\text { Alternative }\end{array}$ & $\begin{array}{c}\text { Cross- } \\
\text { section } \\
\text { One-sided }\end{array}$ & $\begin{array}{c}\text { Period } \\
\text { One- } \\
\text { sided }\end{array}$ & Both \\
\hline Breusch-Pagan & 2.160035 & 7.889343 & 10.04938 \\
& $(0.1416)$ & $(0.0050)$ & $(0.0015)$ \\
\hline
\end{tabular}

Sumber: Eviews, diolah 
Berdasarkan hasil pengujian dengan Uji Lagrange Multiplier (LM) pada Tabel 3 diperoleh nilai LM hitung adalah 0,1416 $>\alpha=0,05$. Hal tersebut mengartikan bahwa nilai LM hitung $>$ chi-squared tabel maka model yang dipilih adalah Random Effect Model.

\section{Hasil Analisis Regresi Data Panel}

Tabel 4. Hasil estimasi dengan Random Effect Model

\begin{tabular}{cccc}
\hline Variable & Coefficient & t-Statistic & Prob. \\
\hline C & -1.213267 & -0.117470 & 0.9070 \\
COR & -0.044347 & -0.901035 & 0.3727 \\
PEDU & 0.002743 & 0.031344 & 0.9751 \\
POP & 0.730024 & 0.993963 & 0.3259 \\
INV & 0.164581 & 2.805457 & 0.0076 \\
OPEN & 0.008232 & 1.304219 & 0.1993 \\
Adjusted R-squared & & 0.198595 & \\
F-statistic & & 3.329400 & \\
Prob(F-statistic) & & 0.012713 & \\
\hline
\end{tabular}

Sumber: Eviews, diolah

Berdasarkan pengujian spesifikasi model regresi data panel sebelumnya, Random Effect Model (REM) telah terpilih 2 (dua) kali, yaitu pada Uji Hausman dan Uji Lagrange Multiplier sedangkan Pooled Regression hanya terpilih pada Uji Chow. Sementara itu, Fix Effect Model (FEM) pada pengujian tidak terpilih sama sekali. Dengan demikian dapat disimpulkan bahwa dari ketiga model tersebut, REM lebih baik dalam menginterprestasikan regresi data panel untuk menjawab penelitian ini. Tabel 4 diatas merupakan hasil estimasi regresi data panel dengan menggunakan pendekatan REM.

Berdasarkan tabel di atas, maka diperoleh persamaan regresi data panel sebagai berikut:

\section{$G D P=-1.213267-0.044347 * C O R+0.002743 * P E D U+$ $0.730024 * P O P+0.164581 * I N V+0.008232 * O P E N$}

Dari persamaan regresi diatas dapat disimpulkan beberapa hasil sebagai berikut. Nilai koefisien konstanta sebesar 1.213267 artinya jika semua variabel independen yang terdapat pada model bernilai nol maka tingkat pertumbuhan GDP per kapita $(G D P)$ masih akan tetap bernilai sebesar 1.213267. Nilai koefisien regresi variabel korupsi (COR) bernilai negatif yaitu sebesar -0.044347 artinya setiap peningkatan 1 angka indeks korupsi diprediksi akan menurunkan tingkat pertumbuhan GDP per kapita $(G D P)$ sebesar -0.044347 dengan asumsi variabel lainnya tetap. Nilai koefisien regresi variabel tingkat partisipasi pendidikan dasar $(P E D U)$ bernilai positif yaitu sebesar 0.002743 artinya setiap peningkatan 1 persen tingkat partisipasi pendidikan dasar diprediksi akan menaikan tingkat pertumbuhan GDP per kapita $(G D P)$ sebesar 0.002743 dengan asumsi variabel lainnya tetap. Nilai koefisien regresi variabel tingkat pertumbuhan penduduk $(P O P)$ bernilai positif yaitu sebesar 0.730024 artinya setiap peningkatan 1 persen tingkat pertumbuhan penduduk diprediksi akan menaikan tingkat pertumbuhan GDP per kapita $(G D P)$ sebesar 0.730024 dengan asumsi variabel lainnya tetap. Nilai koefisien regresi variabel investasi publik (INV) bernilai positif yaitu sebesar 0.164581 artinya setiap peningkatan 1 persen investasi publik diprediksi akan menaikan tingkat pertumbuhan GDP per kapita $(G D P)$ sebesar 0.164581 dengan asumsi variabel lainnya tetap. Nilai koefisien regresi variabel keterbukaan perdagangan (OPEN) bernilai positif yaitu sebesar 0.008232 artinya setiap peningkatan 1 persen keterbukaan perdagangan diprediksi akan menaikan tingkat pertumbuhan GDP per kapita $(G D P)$ sebesar 0.008232 dengan asumsi variabel lainnya tetap.

Berdasarkan data estimasi menggunakan pendekatan Random Effect Model terdapat hasil Uji $t$ antara lain sebagai berikut. Variabel korupsi (COR) menunjukkan hasil tingkat signifikansi $(\mathrm{p}$-value $)=0.3727(>0.05)$. Karena nilai p-value $>\alpha(5 \%)$ maka dengan demikian $H_{0}$ diterima, yang berarti bahwa korupsi (COR) tidak berpengaruh terhadap tingkat pertumbuhan GDP perkapita. Variabel tingkat partisipasi pendidikan dasar (PEDU) menunjukkan hasil tingkat signifikansi $(\mathrm{p}$-value $)=0.9751(>0.05)$. Karena nilai p-value $>\alpha(5 \%)$ maka dengan demikian $H_{0}$ diterima, yang berarti bahwa tingkat partisipasi pendidikan dasar tidak berpengaruh terhadap tingkat pertumbuhan GDP perkapita. Variabel tingkat pertumbuhan penduduk $(P O P)$ menunjukkan hasil tingkat signifikansi $(\mathrm{p}$-value $)=0.3259(>0.05)$. Karena nilai p-value $>\alpha(5 \%)$ maka dengan demikian $H_{0}$ diterima, yang berarti bahwa tingkat pertumbuhan penduduk tidak berpengaruh terhadap tingkat pertumbuhan GDP perkapita. Variabel investasi publik (INV) menunjukkan hasil tingkat signifikansi $(\mathrm{p}$-value $)=0.0076(<0.05)$. Karena nilai p-value $>\alpha(5 \%)$ maka dengan demikian $H_{0}$ ditolak, yang berarti bahwa investasi publik berpengaruh terhadap tingkat pertumbuhan GDP perkapita. Variabel keterbukaan perdagangan $(O P E N)$ menunjukkan hasil tingkat signifikansi $(\mathrm{p}$-value $)=0.1993(>0.05)$. Karena nilai $\mathrm{p}$-value $>\alpha(5 \%)$ maka dengan demikian $H_{0}$ diterima, yang berarti bahwa keterbukaan perdagangan tidak berpengaruh terhadap tingkat pertumbuhan GDP perkapita.

Berdasarkan hasil uji $\mathrm{F}$ terlihat bahwa tingkat Prob (FStatistic) sebesar 0.012713 dan dengan menggunakan tingkat $\alpha 0.05$ atau 5\% maka $H_{0}$ ditolak. Sementara, nilai Adjusted $R$ squared sebesar 0.198595 yang menandakan bahwa tingkat ketepatan model yang digunakan pada penelitian adalah $19.8595 \%$ sedangkan untuk sisanya dipengaruhi oleh faktorfaktor diluar model. Oleh karena itu, dapat disimpulkan bahwa terdapat pengaruh secara simultan antara korupsi $(C O R)$, tingkat partisipasi pendidikan dasar $(P E D U)$, tingkat pertumbuhan penduduk $(P O P)$, investasi publik (INV) keterbukaan perdagangan $(O P E N)$ terhadap tingkat pertumbuhan GDP perkapita $(G D P)$.

\section{Pembahasan Hasil Analisis Data}

Hasil analisis dari Random Effect Model pada variabel korupsi terhadap GDP perkapita menunjukkan bahwa variabel korupsi memiliki hubungan yang negatif namun tidak signifikan terhadap GDP perkapita, hasil analisis ini sama dengan hasil penelitian yang dilakukan oleh Ugur (2012) yang juga meneliti tentang hubungan dan pengaruh variabel korupsi terhadap GDP per kapita dengan menggunakan Meta Regresi Analisis (MRA). Pada hasil penelitian tersebut Ugur (2014) menemukan bahwa sebagaian besar korupsi memiliki hubungan yang negatif terhadap GDP perkapita, namun korupsi tidak memiliki hubugan 
keterpengaruhan yang kuat terhadap GDP perkapita. Hal ini menunjukkan bahwa pengaruh korupsi terhadap GDP perkapita sangat lemah dan bersifat negatif. Pada penelitian tersebut Ugur (2014) juga menemukan bahwa pengaruh korupsi secara langsung terhadap GDP perkapita lebih lemah dibandingkan dengan hubungan tidak langsung. Hal ini menunjukkan bahwa hubungan negatif dari tingkat korupsi dan GDP perkapita di 4 negara ASEAN lebih bersifat hubungan tidak langsung.

Hasil penelitian yang sama juga dikemukakan oleh penelitian yang dilakukan oleh Dzhumashev (2009) yang menemukan bahwa korupsi memiliki hubungan negatif dan tidak memiliki dampak secara langsung terhadap pertumbuhan ekonomi. Hubungan negatif antara pertumbuhan ekonomi dan korupsi lebih mengarah pada penurunan produktifitas akibat dari kurangnya efisiensi dan efektifitas dalam proses produksi Dzhumashev (2009). Hal ini dapat terjadi karena tingkat poduktifias juga dipengaruhi oleh beberapa hal yaitu kualitas lembaga dan juga efektifitas lembaga dalam hal ini yaitu kualitas dan efektifitas layanan publik yang diberikan oleh pemerintah maupun orang yang memiliki kewenangan. Hubungan negatif antara korupsi dengan GDP perkapita juga dapat disebabkan oleh tidak optimalnya sumber daya yang dapat dialokasikan baik dalam proses produksi maupun dalam proses pembangunan. Hal ini dapat terjadi karena adanya kebocoran dalam pendanaan yang digunakan untuk pembiayaan sumber daya, sehingga tidak dapat memperoleh sumber daya secara maksimal. Selain itu, hubungan negatif antara korupsi dengan GDP per kapita juga dapat disebabkan oleh misalokasi sumberdaya, seperti tidak tepatnya sumberdaya yang digunakan baik dalam proses produksi, pembangunan maupun dalam penempatan tenaga sumberdaya manusia. Oleh karena itu, misalokasi tersebut dapat menyebabkan penurunan efektivitas dan efisiensi suatu kegiatan produksi maupun layanan.

Variabel investasi publik memliki hubungan yang positif dan juga signifikan dalam memengaruhi pertumbuhan GDP perkapita di 4 negara ASEAN. Hasil penelitian ini sesuai dengan penelitian yang dilakukan oleh Rabnawaz \& Sohail Jafar (2015) yang menerangkan bahwa investasi publik dan juga GDP perkapita memiliki hubungan yang positif dan juga signifikan. Hal ini menunjukkan bahwa investasi publik yang dilakukan oleh pemerintah di 4 negara ASEAN memiliki hubungan secara langsung dan dapat memengaruhi secara signifikan terhadap GDP perkapita. Hubungan dan keterpengaruhan tersebut dapat terjadi karena investasi publik yang dilakukan oleh pemerintah dibagi dalam beberapa sektor, dari keseluruhan sektor tersebut terdapat berbagai sektor yang dapat menciptakan lapangan pekerjaan bagi tenaga kerja akibat dari adanya investasi publik.

Selain menciptakan lapangan pekerjaan, investasi publik yang dilakukan oleh pemerintah juga dapat menciptakan kesempatan atau peluang usaha bagi masyarakat yang berada disekitar lokasi proyek investasi pemerintah. Oleh karena itu, investasi publik yang dilakukan oleh pemerintah dapat memberikan berbagai multipliyer effect pada perekonomian. Sehingga sesuai dengan hasil analisis yang dilakukan dalam penelitian ini investasi publik memiliki hubungan yang positif dan juga signifikan terhadap GDP perkapita. Karena dengan adanya peningkatan lapangan pekerjaan serta peluang usaha akibat dari adanya investasi publik masyarakat dapat memperoleh pendapatan yang lebih dari sebelum adanya investasi publik.

\section{Simpulan}

Hasil analisis metode regresi data panel menunjukkan bahwa korupsi mempunyai pengaruh negatif terhadap pertumbuhan ekonomi di 4 negara ASEAN meski pengaruhnya tidak signifikan. Hasil tersebut mengindikasikan bahwa dampak yang ditimbulkan oleh korupsi tidak secara langsung berimbas pada pertumbuhan ekonomi melainkan lebih mengarah pada inefisiensi proses produksi dan misalokasi sumber daya. Hal ini terjadi dikarenakan korupsi dapat menurunkan kualitas kelembagaan dan membuat kebocoran dalam pembiayaan sumber daya.

Hasil empiris pada variabel lainnya menunjukkan bahwa hanya investasi publik saja yang mempunyai pengaruh positif signifikan terhadap pertumbuhan ekonomi di 4 negara ASEAN, sedangkan variabel lainnya (tingkat partisipasi sekolah dasar, tingkat pertumbuhan penduduk dan keterbukaan perdagangan) mempunyai pengaruh yang positif namun tidak signifikan. Hasil ini menegaskan bahwa investasi publik yang dilakukan oleh pemerintah mampu menciptakan multiplier effect pada perekonomian seperti menciptakan lapangan pekerjaan bagi tenaga kerja dan kesempatan atau peluang usaha bagi masyarakat.

\section{Referensi}

Acemoglu, D., \& Verdier, T. (1998). Property Rights, Corruption and The Allocation of Talent: A General Equilibrium Approach. Economic Journal, 108(450), 1381-1403. https://doi.org/10.1111/14680297.00347

Barreto, R. A. (2001). Endogenous Corruption, Inequality and Growth: Econometric Evidence. In Europeaan Economic Review (Vol. 44, Issue 1).

Barro, R. J. (1991). Economic Growth in a Cross Section of Countries. The Quarterly Journal of Economics, 106(2), 407-443. https://doi.org/10.2307/2937943

Colombatto, E. (2003). Why is corruption tolerated? Review of Austrian Economics, $16(4)$, https://doi.org/10.1023/A:1027349206371

d'Agostino, G., Dunne, J. P., \& Pieroni, L. (2016). Corruption and Growth in Africa. European Journal of Political Economy, 43, 1-35. https://doi.org/10.1016/j.ejpoleco.2016.03.002

Dreher, A., \& Herzfeld, T. (2011). The Economic Costs of Corruption: A Survey and New Evidence. SSRN Electronic Journal, June. https://doi.org/10.2139/ssrn.734184

Dridi, M. (2013). Corruption and Economic Growth: The Tranmission Channels. Journal of Business Studies Quarterly (No. 47873).

Dzhumashev, R. (2009). Is there a direct effect of corruption on (Issue 18489).

Gyimah-Brempong, K. (2002). Corruption, economic growth, and income inequality in Africa. Economics of Governance, 3, 183-209. https://doi.org/10.1007/s101010200045

Huntington, S. P. (1968). Political Order in Changing Societies. In Political Order in Changing Societies. https://doi.org/10.5771/0506-72861970-2-257

Leff, N. H. (1964). Economic Development Through Bureaucratic Corruption. American Behavioral Scientist, 8(3), 8-14. https://doi.org/10.1177/000276426400800303

Levine, R., \& Renelt, D. (1992). A Sensitivity Analysis of Cross-Country Growth Regressions. American Economic Review, 82(4), 942-963. https://doi.org/10.2307/2117352

Leys, C. (1965). What is The Problem About Corruption? The Journal of Modern African Studies, 3(2), 215-230. https://doi.org/10.1017/S0022278X00023636

Lui, F. T. (1985). An Equilibrium Queuing Model of Bribery. Journal of $\begin{array}{lll}\text { Political Economy, 93(4), 760-781. } & \text {. }\end{array}$ http://www.jstor.org/stable/1832136

Mauro, P. (1995). Corruption and Growth. The Quarterly Journal of 
Economics, 110(3), 681-712. https://doi.org/10.2298/fid1301021m

Mo, P. H. (2001). Corruption and Economic Growth. Journal of Comparative Economics, 29(1), 66-79. https://doi.org/10.1006/jcec.2000.1703

Murray, M. P. (1946). Econometrics : A Modern Introduction. Pearson International ed.

Myrdal, G. (1968). An Inquiry into the Poverty of Nations. The Australian Quarterly, 40(4), 118-121. https://doi.org/10.2307/20634250

Paksha Paul, B. (2010). Does corruption foster growth in Bangladesh? International Journal of Development Issues, 9(3), 246-262. https://doi.org/10.1108/14468951011073325

Poirson, H. (1998). Economic Security, Private Investment, and Growing in Developing Countries.

Rabnawaz, A., \& Sohail Jafar, R. (2015). Impact of Public Investment on Economic Growth. Munich Personal RePEc Archive, 70377, 1-14. https://doi.org/10.2139/ssrn.2796368

Rose-Ackerman, S. (1996). The Political Economy of Corruption- Causes and Consequences. In Development (No. 74).
Shera, A., Dosti, B., \& Grabova, P. (2014). Corruption Impact on Economic Growth: An Empirical Analysis. Journal of Economic Development, Management, IT, Finance and Marketing, 6(2), 57-77.

Sunengsih, N., Regresi, A., \& Panel, D. (2009). Kajian Analisis Regresi Dengan Data Panel.

Tanzi, V. (1998). Corruption Around The World: Causes, Consequences, Scope and Cures.

Tsaturyan, S., \& Bryson, P. J. (2009). Corruption and Development: The Armenian Case. International Journal of Economic Policy in Emerging Economies, 2(4), 356-371. https://doi.org/10.1504/IJEPEE.2009.030937

Ugur, M. (2014). Corruption's direct effects on per-capita income growth: A meta-analysis. Journal of Economic Surveys, 28(3), 472-490. https://doi.org/10.1111/joes.12035

Wedema, A. (1997). Corruption and Growth in Zaire, South Korea, and the Philippines. The Journal of Developing Areas, 31(4), 457-478. 